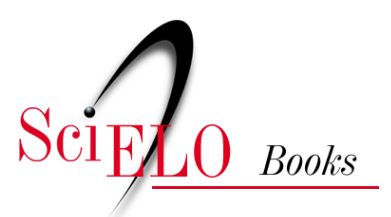

\title{
Reflexões \\ Cuide bem de sua memória
}

\author{
Nelson De Luca Pretto
}

PRETTO, N.D.L. Cuide bem de sua memória. In: Educações, culturas e hackers: escritos e reflexões [online]. Salvador: EDUFBA, 2017, pp. 133-135. ISBN: 978-85-232-2019-8.

https://doi.org/10.7476/9788523220198.0027.

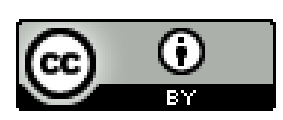

All the contents of this work, except where otherwise noted, is licensed under a Creative Commons Attribution $\underline{4.0 \text { International license. }}$

Todo o conteúdo deste trabalho, exceto quando houver ressalva, é publicado sob a licença Creative Commons Atribição 4.0.

Todo el contenido de esta obra, excepto donde se indique lo contrario, está bajo licencia de la licencia Creative Commons Reconocimento 4.0. 
ral, buscando-se outras formas de licenciamento desses produtos (aliás, vi pouco destaque sobre essa temática aqui no CINEOP). Sinto necessidade de avançar no debate sobre o uso hardwares e softwares livres para a produção audiovisual e, complementarmente, sobre a intensificação do uso de formatos abertos e livres.

Não quero me alongar no texto, mas creio que CINEOP e a Rede Kino têm um papel fundamental no enfreamento dessas questões. Portanto, vida longa para ambos e que continuem juntos.

Termino, trazendo um fragmento de Glauber Rocha (de 2004) citado por Gilmar Rocha no bom livro Revolução 2.0, organizado por Giuseppe Cocco que, por coincidência, acabo de ler.

Glauber:

"O cineasta do Terceiro Mundo não deve ter medo de ser 'primitivo'. Será naif insistir em imitar a cultura dominadora. Também será naif se se fizer patrioteiro".

Portanto, sejamos primitivos. E ganhemos o mundo, como fez Glauber.

Publicado no jornal Correio*, Salvador, em 5 de junho de 2015.

\section{Cuide bem de sua memória}

Futuco coisas daqui e dali para tentar localizar documentos e imagens que me ajudem a (re)construir e analisar um pouco o passado recente porque ando trabalhando na finalização de um novo livro. Com um título que deve ser Uma dobra no tempo, o livro é fruto do memorial que apresentei em dezembro passado [2015] para minha progressão a professor titular da Universidade Federal da Bahia (UFBA). Tenho uma verdadeira obsessão 
por memória e estou resgatando interessantes materiais para essa nova produção.

Pois, justo na semana passada, leio na BBC um alerta feito por Vint Cerf ${ }^{28}$, conhecido como o pai da internet, sobre a possibilidade de um futuro sombrio para a chamada era digital, por conta da impossibilidade de muitos equipamentos lerem os arquivos de imagens, sons, vídeos e textos hoje produzidos.

Em 21 de junho de 2006, já escrevia no jornal A Tarde, de Salvador, o artigo Memória Perdida, onde alertava sobre o crescente uso das máquinas digitais para as fotografias pessoais e as dificuldades que poderíamos ter no armazenamento dessas fotos, o que poderia se "configurar um grande vazio imagético para o nosso início de milênio."

Não estava sendo profético, estava só alertando para o mesmo que Vint Cerf, hoje uma autoridade na empresa Google, traz à tona. Tudo porque, se não estivermos atentos, poderemos ter, num futuro até breve, imagens e documentos que não serão mais lidos pelos equipamentos disponíveis na época. Já vivemos isso com muitos dos nossos materiais e, justo por isso, nossa verdadeira batalha em defesa dos softwares e hardwares livres e dos formatos abertos. Precisamos fortalecer a formação da nossa juventude com esse espírito de liberdade que está associado a todos esses movimentos e essa é uma tarefa urgente da escola.

A educação, em todos os níveis, deveria ter a adoção dos formatos abertos e da preservação de sua memória como um princípio básico, visando garantir para o futuro a possibilidade de se conhecer e analisar nosso rico percurso histórico.

Precisamos atuar de forma mais intensa nessa perspectiva, em oposição à formação para o consumo, centrada na obsolescência e na não preservação, seja dos objetos/equipamentos, seja da nossa história e, com isso, volto ao tema das minhas próprias memórias.

Tento resgatar um importante evento do qual participei na década de 1980, o I Encontro Brasileiro de Educação e Televisão, promovido pelo Inep, em conjunto com a Fundação Brasileira de TV Educativa, a Funtevê da época, hoje a Empresa Brasileira de Comunicação (EBC). O Encontro,

\footnotetext{
${ }^{28}$ Disponível em: <http://www.bbc.com/news/science-environment-31450389>. Acesso em: $1^{\circ}$ abr. 2017.
} 
realizado no Hotel Nacional, em Brasília, em junho de 1987, foi todo gravado pela TVE do Rio de Janeiro (Funtevê).

Lembro como se fosse hoje que a programação foi sensacional e tivemos depoimentos absolutamente geniais sobre a história da televisão brasileira e a sua relação com a educação. Há mais de dois anos que provoco pessoas conhecidas na EBC para a localização dessas importantes fitas. Até agora esse material não foi encontrado e tenho pouca esperança de que venha sê-lo. Nesses últimos dias, recebo do gerente de Documentação e Pesquisa da EBC um e-mail com informações estarrecedoras sobre a situação desse rico acervo, que tem imagens do Brasil e dos brasileiros de, pelo menos, dos últimos 50 anos. Segundo afirma Bruno Rasga, são cerca de 150 mil fitas no antigo formato Betacam; portanto, com uma enorme dificuldade de serem preservadas, pois são poucos os equipamentos disponíveis que ainda leem esse antigo formato. Já existe um projeto para digitalização desse material e, segundo ele, foi incluído no planejamento estratégico da empresa para 2015, mas, em períodos de vacas magras, ficamos todos apreensivos se, de fato, alguma coisa será feita para essa preservação.

A situação me parece dramática, pois, com o passar do tempo e a proposital obsolescência tecnológica andando a passos largos, corremos o risco de não ter preservadas as importantes imagens de nosso passado recente e, com isso, perdemos todos, pois não se constrói uma pátria educadora se nossa memória vira lixo. 